\title{
Growing Strawberries in the Florida Home Garden ${ }^{1}$
}

\author{
Vance M. Whitaker, Natalia A. Peres, Sriyanka Lahiri, Sydney Park Brown, and Craig K. \\ Chandler $^{2}$
}

Florida is the winter strawberry capital of the world. In commercial and home production, strawberries are grown as an annual crop rather than as perennials. This publication presents guidelines for the successful production of strawberries in the Florida home garden.

Temperatures between $50^{\circ} \mathrm{F}$ and $80^{\circ} \mathrm{F}\left(10^{\circ} \mathrm{C}\right.$ and $\left.27^{\circ} \mathrm{C}\right)$ and day lengths 14 hours or less are required for the development of flowers and fruit on most strawberry varieties. In areas of the United States north of Florida (except for the coastal areas of southern and central California), these conditions occur only for a short period in the late summer or early fall, and again briefly in the spring. In peninsular Florida, however, these conditions exist for much of the fall, winter, and spring. Single-crown (stem) strawberry plants are planted in Florida during the fall, from late September to early November. Flowering and fruit production generally begins in November and continues into April or May. Fruit production over this period is not constant, but occurs in two or three cycles, and can be interrupted by freezing weather. Because the highest quality fruit are produced on relatively young plants with not more than four or five branch crowns, plants are usually removed at the end of the fruiting season, and new plants are planted the following fall.

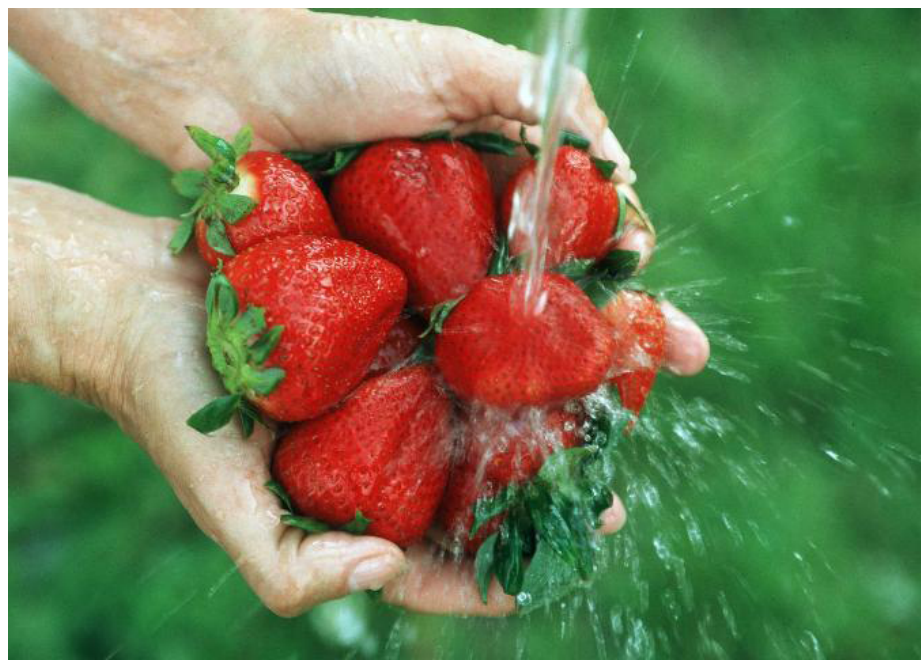

Figure 1. Florida strawberries are grown as an annual crop and harvested in late fall, winter, and early spring.

Credits: UF/IFAS

\section{Varieties}

Currently, three varieties are suggested for the Florida home garden: 'Camarosa,' 'Florida Brilliance', and Sweet Sensation $^{\text {tw }}$ 'Florida127'. All three varieties produce attractive, flavorful berries suitable for eating fresh or for freezing. 'Camarosa' has been the most productive variety in North Florida, while 'Florida Brilliance' and Sweet Sensation ${ }^{\mathrm{TM}}$ 'Florida127' produce more fruit during the early part of the season and have been the most productive varieties for commercial production in Central Florida. These varieties are capable of producing 1 to 2 pints of fruit per plant over the season.

1. This document is HS1154, one of a series of the Horticultural Sciences Department, UF/IFAS Extension. Original publication date December 2008. Revised December 2014 and September 2021. Visit the EDIS website at https://edis.ifas.ufl.edu for the currently supported version of this publication.

2. Vance M. Whitaker, associate professor, Horticultural Sciences Department; Natalia A. Peres, professor, Plant Pathology Department; Sriyanka Lahiri, assistant professor, Entomology and Nematology Department; Sydney Park Brown, associate professor, Environmental Horticulture Department; and Craig K. Chandler, professor emeritus, Horticultural Sciences Department; UF/IFAS Extension, Gainesville, FL 32611.

The Institute of Food and Agricultural Sciences (IFAS) is an Equal Opportunity Institution authorized to provide research, educational information and other services

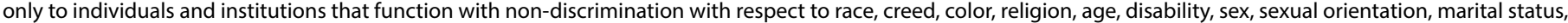

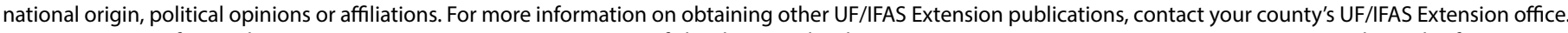
U.S. Department of Agriculture, UF/IFAS Extension Service, University of Florida, IFAS, Florida A \& M University Cooperative Extension Program, and Boards of County Commissioners Cooperating. Nick T. Place, dean for UF/IFAS Extension. 


\section{General Growing Conditions}

Strawberries grow best in a location receiving at least 8 hours of direct sunlight per day. If a full sun location is not available, choose a spot that is sunny during the morning and early afternoon. The soil should be well drained and slightly acidic (pH 5.5-6.5).

Most strawberry plants grown commercially in Florida are planted in double rows on soil that has been mounded into raised beds (Figure 2). This method also is recommended for home gardens. Raised beds (as compared to flat beds) create a well-drained soil environment in which roots have sufficient oxygen for survival during periods of heavy rain.

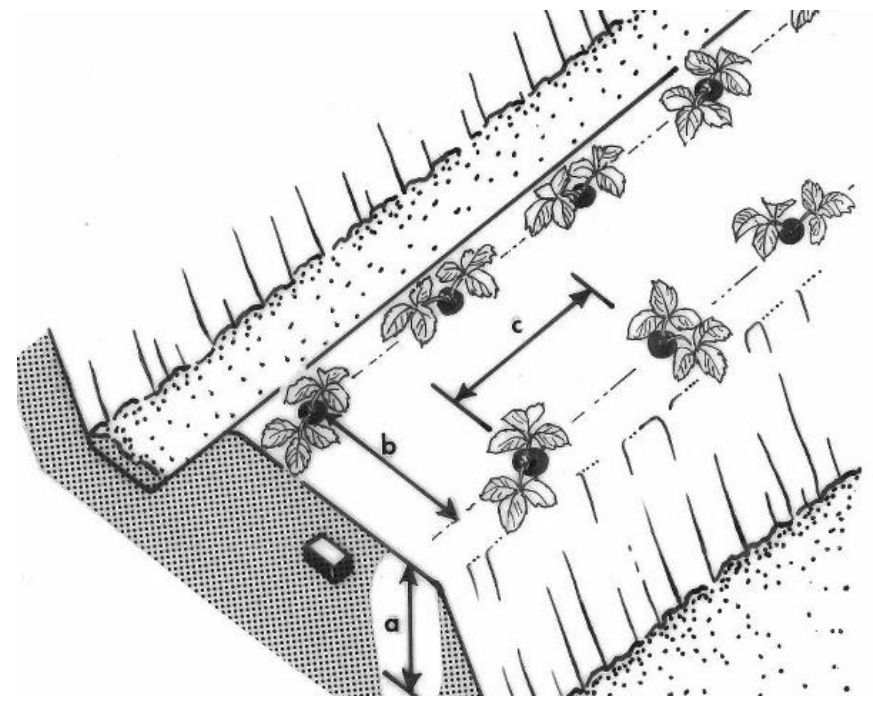

Figure 2. Raised bed design recommended for Florida garden strawberries ( $a=7-9$ inches; $b=12$ inches; $c=12-18$ inches). Credits: Redrawn from Integrated Pest Management for Strawberries, 1994. University of California Division of Agriculture and Natural Resources Publication 3351, p. 129.

Two pounds ( $900 \mathrm{~g}$ ) of 10-5-10 (or equivalent) garden fertilizer with micronutrients (including boron) per 10 feet of row should be incorporated into the bed before planting. About one-half of the nitrogen in the fertilizer should be in a slow release form, such as a sulfur- or resin-coated material. Incorporate one-fourth of the fertilizer evenly across the top of the bed with a steel rake. Apply the remainder of the fertilizer in a narrow band approximately 1 inch $(2.5$ $\mathrm{cm}$ ) deep along the middle of the bed (above the drip line or soaker hose, if they have been placed in the bed).Drip irrigation tape or tubing can be laid (emitter side up) in a 2 to 3 inch deep trench down the center of the bed. One to two inches of soil are placed on top of the tubing. Raised beds also make hand harvesting easier. Black polyethylene sheeting ( 1 to 1.5 mils thick) on 48 to 60 inch (122-152 $\mathrm{cm}$ ) wide rolls is most often used to cover the raised beds. It provides excellent weed control and keeps the fruit cleaner than if it were lying directly on the soil surface. Colored sheeting other than black can be used, provided it is opaque. Clear sheeting is not recommended because it does not provide adequate weed control.

Transplants are set through slits made in the polyethylene mulch. Bare-root plants are the most common type of transplant available. These transplants may or may not have leaves on them. Those with leaves on them at the time of transplanting generally produce greater early season fruit yield than those without leaves on them at the time of transplanting. Bare-root transplants with leaves on them, however, usually require frequent sprinkler irrigation from about 10 a.m. to 5 p.m. for the first 1 to 2 weeks after transplanting. Another type of transplant is the plug or containerized transplant. This type of transplant may be available in plastic trays or in small plastic or fiber pots. Since the root system of this type of transplant typically stays intact when the plant is pulled from its container, very little sprinkler irrigation is needed after transplanting. Regardless of the type of transplant used, it is important not to set the transplant too deeply, covering the crown, or too shallowly, leaving roots exposed.

After the plants are established on the bed (i.e., when leafy bare-root transplants no longer have a tendency to wilt during the hottest part of the day), drip tape or soaker hoses can be used to keep the beds moist. Watering at a low pressure (e.g., $10 \mathrm{psi}$ ) for $1 / 2$ to 1 hour should thoroughly moisten the bed. Beds can also be watered with overhead sprinklers. Early in the season when the plants are small, one watering per week may be sufficient. Later in the season, when the plants are larger and weather is warmer, two or three waterings per week will be needed.

Strawberry plants also can be grown in planter boxes, strawberry pots, barrels, and other types of containers.

\section{Freeze Protection}

Strawberry flowers and fruit can be damaged by air temperatures below $32^{\circ} \mathrm{F}\left(0^{\circ} \mathrm{C}\right)$. Leaves and crowns of the plants that have become acclimated to cool fall and winter weather usually do not sustain any permanent damage unless they are exposed to air temperatures in the low 20s. The most practical method for the Florida gardener to protect flowers from freeze damage may be to cover plants with sheets, blankets or frost cloth. Cover during the afternoon preceding an expected freeze. The covering should be anchored down on all sides to prevent wind from blowing it off the plants. A small "tunnel" can also be constructed using PVC hoops covered with clear plastic sheeting to create 
a greenhouse effect. The sides can be raised or lowered depending on air temperatures.

\section{Pest Management}

One of the keys to successful pest management of strawberries in Florida is to start with healthy transplants-especially plants free of root diseases, spider mites, and nematodes. Home gardeners face an uphill battle if they start the season with diseased or infested plants. Plants are best purchased from a reputable nursery or garden center.

To control most diseases on leaves, flowers, and fruit, the Florida gardener can apply a protectant fungicide spray product that is formulated for home garden use. Be sure that strawberry is listed on the label, and carefully follow label directions. Removing old, diseased leaves and fruit from the plants may help to reduce future leaf and fruit infections. Powdery mildew, a fungal disease that results in leaf distortion and powdery white patches on the underside of leaves, is usually brought under control with several spray applications of sulfur. Sulfur should be applied when the air temperature is less than $80^{\circ} \mathrm{F}\left(27^{\circ} \mathrm{C}\right)$ to reduce the chance of causing foliage or fruit burn.

Damaging insects generally change as the season progresses. Early in the season (i.e., October and November), various types of caterpillars ("worms") are often found feeding on crown, leaf, or young flower tissue. Applications of either Bacillus thuringiensis (Bt.) or a neem seed extract with the active ingredient azadirachtin will usually control small caterpillars. Both are "organic" products available from retail garden centers. Bifenthrin (pyrethroid) is permitted and effective for armyworm control but pyrethroids in general are damaging to many naturally occurring beneficial insects and mites. Bifenthrin can also exacerbate thrips problems so its use on strawberries should be avoided if possible. For example, invasive thrips pest, chilli thrips (Scirtothrips dorsalis), which infest young strawberry leaves, are resistant to bifenthrin. Of course, caterpillars in small plantings can be removed and destroyed by hand.

Later in the season, aphids or flower thrips may cause some damage to developing fruit. Neem products, insecticidal soap, and mineral oils are the preferred products to control these pests in the home garden, although natural predators and parasites in the home garden usually will take care of the problem, if the gardener has patience. Lacewings (Figure 3), ladybird beetles, minute pirate bugs (Figure 4), and predatory stink bugs are among the predators that help suppress pests in strawberry. Aphids also are attacked by several types of parasitic wasps. Parasitized aphids are called "mummies" and have a distinctive appearance (Figure 5).

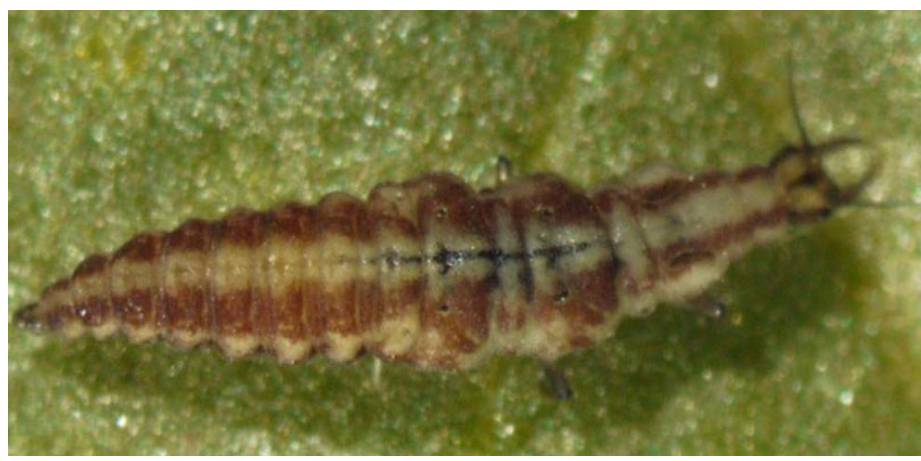

Figure 3. Lacewing larva. Lacewings feed on many pests of strawberry, including aphids.

Credits: Hugh Smith, UF/IFAS

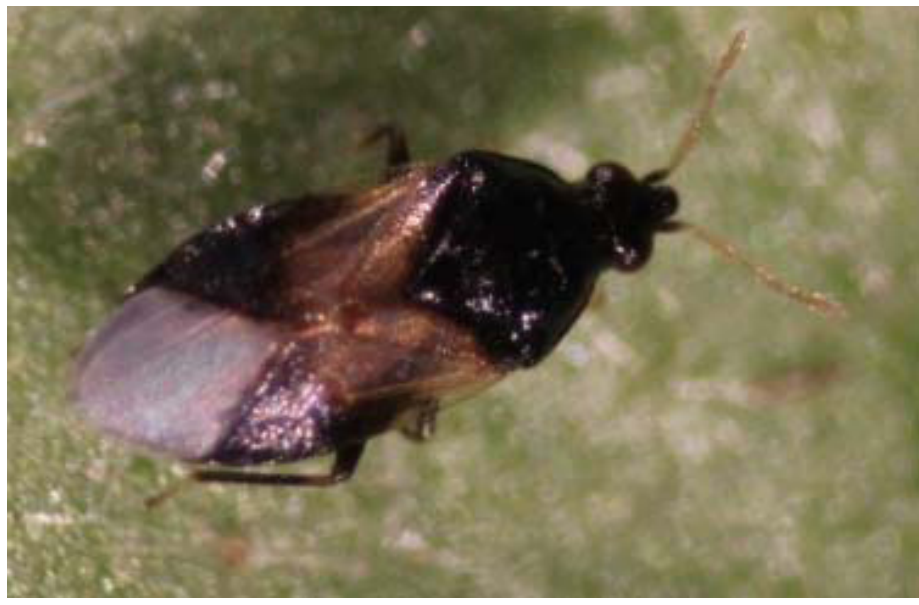

Figure 4. Minute pirate bug, also called Orius. Minute pirate bugs feed on thrips and other pests.

Credits: Hugh Smith, UF/IFAS

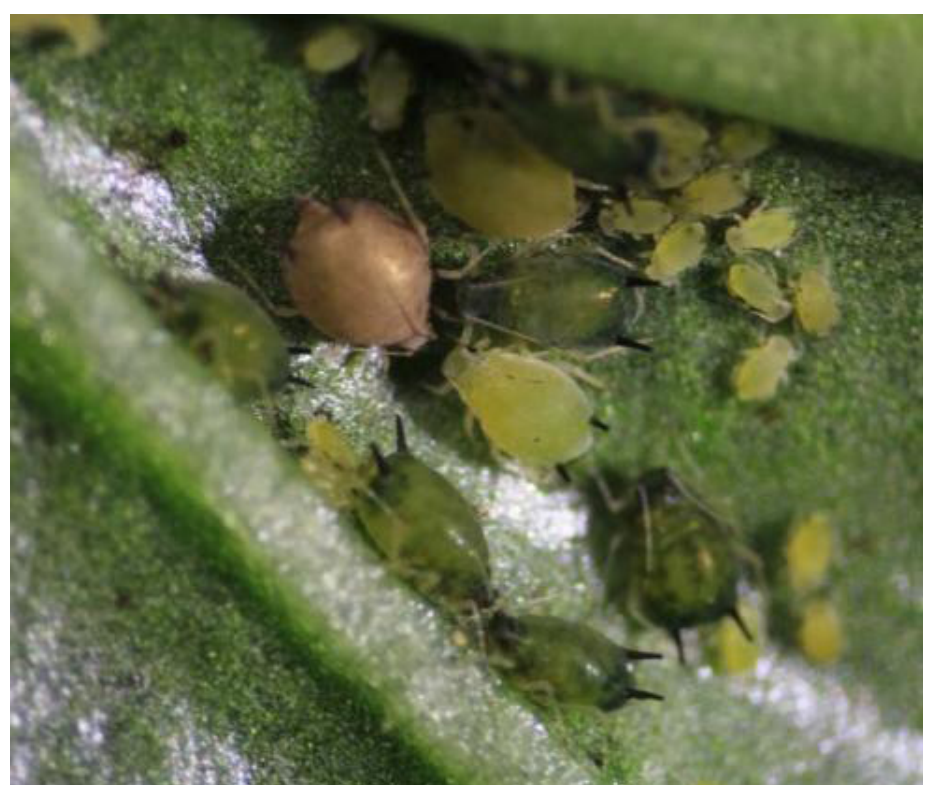

Spider mites (tiny arthropods that suck juices from plant leaves) are generally a more persistent problem on strawberries in Florida than are insects (Figure 6). Start examining plants for spider mites in early December, looking 
especially for plants that have leaves with small patches of yellow, pin prick-size stipples showing through the upper leaf surface. A hand lens can be used to see the mites moving about on the underside of leaves. If mites are found on 5 percent or more of the leaflets examined, it is likely that the population needs to be controlled with applications of a home garden pesticide such as a neem product, insecticidal soap, or mineral oil. These products are most effective when two applications are made (or even three when infestations persist), spaced approximately 5-7 days apart. Before using any pesticide, be sure to read and follow all label directions. Predatory mites (Phytoseiulus persimilis) are highly effective in controlling spider mite outbreaks and are readily used by strawberry farmers who purchase and apply them. Other commercially available predatory mites that feed on mites, thrips, and other small insets include Amblyseius swirskii, Neoseiulus cucumeris, and Neoseiulus californicus. Unfortunately, buying and releasing beneficials is not very feasible for the typical home gardener due to the large quantities that must be purchased and the associated shipping costs. Links to more information on Integrated Pest Management (IPM) in strawberries can be found at the end of this publication.

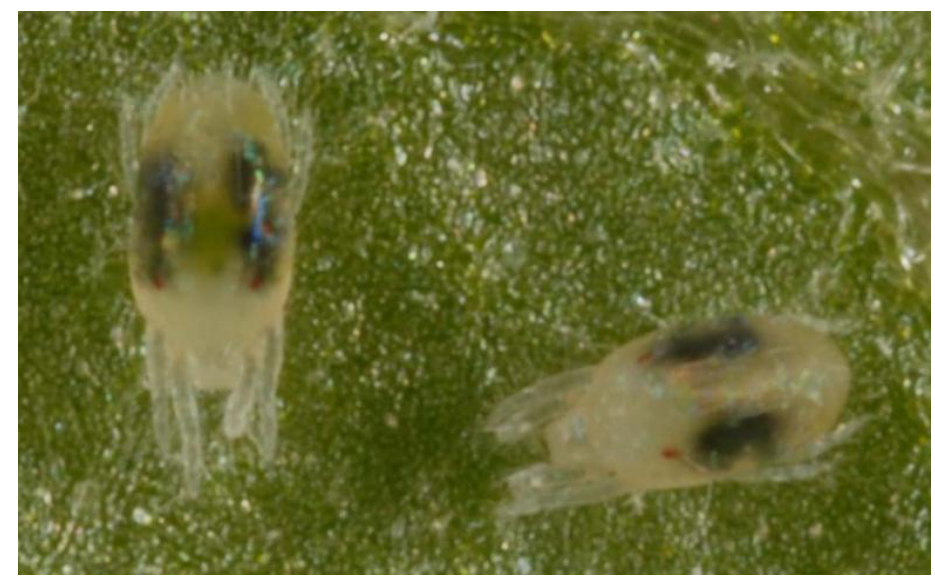

Figure 6. Two-spotted spider mite.

Credits: Lyle Buss, UF/IFAS

Parasitic nematodes (microscopic round worms in the soil) and certain soil-borne pathogens can cause problems if strawberry plants are set in the same area year after year. It is advisable to switch your planting to an area that has not been planted in strawberries for two or three years. Avoid planting strawberries in areas where you have just grown tomatoes, potatoes, eggplant, or other vegetable crops that are susceptible to Verticillium wilt. Solarizing the soil during the summer before planting can also help to reduce soil-borne pests and pathogens (see https://edis. ifas.ufl.edu/publication/NG005). UF/IFAS Extension offices have information on this process: http://sfyl.ifas.ufl.edu/ find-your-local-office/.
Although bird pests, such as robins and cedar waxwings, are difficult to control in commercial plantings of strawberries, they can be excluded from small garden plantings by covering the plants with bird netting.

\section{Harvesting And Storage}

A strawberry fruit is ready to harvest when three quarters of its entire surface area is red. The fruit starts to deteriorate soon after it has become totally red, so it is best to harvest fruit regularly, generally, every two to four days. Ripe strawberries are delicate and bruise easily, so a gentle picking technique is recommended. Fruit that is held between the thumb and forefingers can be snapped from the fruit stem (pedicel) by twisting the forearm and wrist. Strawberries that are not going to be consumed immediately after harvest should be frozen or placed in a refrigerator, preferably in a moisture proof container to keep them from drying out.

\section{For More Information}

Introduction to Soil Solarization: https://edis.ifas.ufl.edu/ publication/IN856

\author{
'Florida Brilliance' Strawberry: https://edis.ifas.ufl.edu/ \\ publication/hs1322
}

\begin{abstract}
Sweet Sensation ${ }^{\mathrm{Tm}}$ 'Florida 127': https://edis.ifas.ufl.edu/ publication/HS1256
\end{abstract}
Strawberries: Main Pests and Beneficials in Florida: https:// ipm.ifas.ufl.edu/pdfs/HS26500.pdf

Predatory Mite: https://edis.ifas.ufl.edu/publication/in639

Arbico Organics: https://www.arbico-organics.com/ product/mite-predator-phytoseiulus-persimilis-spidermitekiller-greenhouse/796?gclid=Cj0KCQjwvO2IBhCzARIsAL w3ASrHbQW7Ce9-egqPkT5DbI3Z5BKw0XvpxPSbkZDYWE8ctnqz43JfXOAaAu8mEALw_wcB

Gardening Zone: https:/gardeningzone.com/products/ amblyseius-swirskii-1-000-adults

https://gardeningzone.com/products/ phytoseiulus-persimilis-for-spider-mite-control

\section{Acknowledgments}

Dr. Hugh Smith, associate professor, UF/IFAS Entomology and Nematology Department, contributed information on insects and mites in the original version of this document. 